TERRY EAGLETON

Święty terror

Przeł. Jacek Konieczny

Wydawnictwo Znak, Kraków 2008, ss. 221

\title{
WOJCIECH SOWIŃSKI
}

Toruń

\section{Terroryści na czele cywilizacji?}

$\mathbf{N}$

akładem krakowskiego wydawnictwa Znak ukazał się zbiór esejów T. Eagletona (ur. 1943 r.) zatytułowany Święty terror (w oryginale: Holy Terror - The Meaning of Terrorism). Autor jest jednym z czołowych przedstawicieli brytyjskich intelektualistów skrajnej lewicy. Znamienne dla sposobu prezentowania przez niego poglądów są nade wszystko częste nawiązania do dorobku literatury i kultury. Dotychczas w przekładzie na język polski ukazały się dwie wcześniejsze publikacje Eagletona: Iluzje postmodernizmu i Marks. Marks $i$ wolność. Warto także odnotować, iż oryginalna, angielska wersja Świętego terroru ukazała się w $2005 \mathrm{r}$.

Zasadniczym przedmiotem uwagi autora $\mathrm{w}$ recenzowanej pracy jest krytyczne odniesienie się do doktryny politycznej wspierającej działania poprzedniego, republikańskiego rządu Stanów Zjednoczonych. W Świętym terrorze rozwija on myśl, iż koncepcja tzw. wojny z terroryzmem jest w ustach politycznych reprezentantów współczesnej zachodniej cywilizacji hasłem nade wszystko przepełnionym hipokryzją, a efekty jego wprowadzania w życie prowadzą do kompromitacji nie tylko rządzących, ale całego kojarzonego z Europą i Ameryką Północną systemu wartości ${ }^{1}$. Terroryzm jest bowiem, według autora, wspólnym mianownikiem zarówno świata islamskiego fundamentalizmu, jak i wywodzącego się z tradycji grecko-rzymskiej i chrześcijańskiej świata Zachodu. Główną tezę publikacji upatruję we fragmencie poświęconego pojęciu wolności eseju zatytułowanego Strach $i$ wolność, gdzie Eagleton wskazuje, iż: „Kiedy jakieś państwo broni się przed fundamentalizmem, pozbawiając własnych obywateli wolności, można uznać, że obie

T. Eagleton, Święty terror, Kraków 2008, s. 83. 
strony zarazem odnoszą zwycięstwo i ponoszą porażkę"”2. W takim właśnie duchu autor stawia opór tezie wieszczącej nadchodzące „zderzenie cywilizacji" .

Warto w tym miejscu, choćby w skrótowej formie, zwrócić uwagę na najbardziej znamienne fragmenty pracy.

Pierwszy ze zbioru esej nosi tytuł Zachęta do orgii, a celem, jaki sobie w nim autor postawił, jest wykazanie ścisłego związku brutalnego i bezwzględnego terroru z dwoma bezsprzecznymi fundamentami cywilizacji zachodniej - tradycją antyku i chrześcijaństwem. T. Eagleton w szczególności poddaje w tym miejscu analizie jeden z dramatów Eurypidesa, Bachantki, w którym dochodzi do spotkania dwóch archetypicznych postaci: starającego się chronić swych poddanych króla Teb, Penteusza, z prymitywnym, wulgarnym i brutalnym Dionizosem. Przyglądając się temu spotkaniu, Eagleton wyraża pogląd o swoistym pokrewieństwie reprezentujących odmienne wartości bohaterów. Wskazuje on mianowicie, iż „Anarchia i absolutyzm to awers i rewers tego samego zjawiska. Przedstawiciele obu nurtów podejrzewają, że chaos jest naturalnym stanem ludzkości, tyle tylko, że absolutyści się go boją, a anarchiści się nim upajają" ${ }^{4}$.

W eseju Strach $i$ wolność Eagleton, jakkolwiek dając bezpośrednio wyraz inspiracjom marksistowskim, zwraca uwagę na okoliczność, iż niemożliwe do pominięcia korzenie współczesnego ustroju liberalnego sięgają krwawego jakobinizmu rewolucji francuskiej ${ }^{5}$. W świetle głoszonych przez autora poglądów wydarzenia związane $\mathrm{z}$ tzw. wielkim terrorem to kolejne wcielenie destrukcyjnego i nihilistycznego oblicza cywilizacji Zachodu, które jest dla niej naturalne i zarazem charakterystyczne od samego jej zarania. Skoro już wspomniano rewolucję francuską, która przecież stała się punktem zwrotnym w historii gospodarczej, prowadząc do triumfu kapitalizmu, nie sposób pominąć milczeniem niezwykle wyrazistego stanowiska autora Świętego terroru, który wprost zdecydował się sam kapitalizm mianować wszechobecną i niemożliwą do pokonania przez zniewolone społeczeństwo odmianą terroryzmu ${ }^{6}$. Nadmienić trzeba, iż w tym samym szeregu postawiony zostaje również ruch tzw. neokonserwatyzmu ${ }^{7}$.

Niewątpliwie przykuwa uwagę czytelnika dokonane przez autora porównanie będące myślą przewodnią Świętych i samobójców. Oto bowiem Eagleton, wskazując na charakterystyczny dla owych typów osobowych prymat

\footnotetext{
Tamże, s. 116.

Zob. S. Huntington, Zderzenie cywilizacji, Warszawa 2005.

T. Eagleton, Święty terror, s. 48.

Tamże, s. 125 .

Tamże, s. 130.

Tamże, s. 134.
} 
ducha nad materią i doczesnością, zestawia ze sobą następujące postaci: świętego chrześcijańskiego, osobę podejmującą strajk głodowy oraz islamskiego terrorystę samobójcę. Zdaniem autora grupę tę łączy nade wszystko motywacja samobójcza (samobójstwo rozumiane jest tutaj w szeroki sposób, obejmujący m.in. także postrzegane jako świadectwo wiary męczeństwo), którą paradoksalnie należy potraktować jako najwyższy akt woli, swoisty ideał kultywującego indywidualizm jednostki świata współczesnego Zacho$\mathrm{du}^{8}$.

W publikacji T. Eagletona wyraźnie wysuwa się na pierwszy plan, eksponowana swego czasu szczególnie przez W. Lenina ${ }^{9}$, obawa przed instytucją państwa jako takiego. Pod koniec eseju Żywe trupy autor zwraca bowiem uwagę na wzajemne sprzęgnięcie się instytucji państwa, którego zadaniem jest, przede wszystkim, szeroko rozumiana ochrona obywateli i które ze swej definicji antycypuje państwo terroryzmu ${ }^{10}$. Inaczej mówiąc, im bardziej zaufamy Lewiatanowi, na tym większe starty narazimy nie tylko jego samego, ale również własne poczucie bezpieczeństwa, które nadszarpnięte zostanie nie tylko przez terrorystów, ale również przez naszego „pozornego” obrońcę.

Na potrzeby prezentowania swej, niewątpliwie frapującej, tezy o bliskim pokrewieństwie kultury opartej na tradycjach antycznych i chrześcijańskich Europy z terroryzmem islamskim początków XXI wieku Eagleton zdaje się pomijać niektóre aspekty zachodzącego od dawna antagonizmu dwóch cywilizacji. Otóż wydaje się, że rozbudowując swój wywód o kolejne dowody, zaczerpnięte głównie z zachodniego dorobku literatury, zbyt mało uwagi poświęcił roli samych religii i tego, w jakich relacjach stawiają one względem siebie Boga i człowieka. Znamienne jest wszak, iż Allach jest w świecie islamu Bogiem nieskończenie transcendentnym, natomiast Bóg chrześcijan nie tylko spotkał się z ludźmi bezpośrednio, ale nawet stał się Człowiekiem, co w planie zbawienia było konieczne i nieuniknione. W konsekwencji w świecie islamu zawsze pozostaną aktywne radykalne nurty głoszące dżihad w imię Absolutu wymagającego bezwzględnego i oderwanego od doczesności posłuszeństwa, zaś oparty na dokonanej już w Nowym Testamencie syntezie antyku i przesłania Jezusa z Nazaretu świat Zachodu pozostawać będzie przywiązany do postulatu odrzucenia sprzeciwiającej się naturze Boga i człowieka przemocy ${ }^{1}$.

Tamże, s. 156.

Zob. W. Lenin, Państwo a rewolucja, [w:] Lenin - Dzieła wybrane, t. II, Warszawa 1949.

T. Eagleton, Święty terror, s. 193.

Niniejszą myśl wywodzę wprost z treści wykładu Benedykta XVI wygłoszonego w dniu 12 września 2006 r. w Ratyzbonie. Lektura początkowej części owego wykładu nasuwa wniosek, iż jednym z motywów głoszącego go Ojca Świętego było wyraźne i wyrażone bezpo- 
Uważam za stosowne zasygnalizowanie, iż autor pracy wielokrotnie powtarza na kartach publikacji, moim zdaniem zbędne dla głównego wywodu oraz nieoparte na rzeczowych argumentach, tezy jednoznacznie świadczące o jego ignorancji względem teologii judaizmu i chrześcijaństwa. Dość wspomnieć ewidentne kpiny i nadużycia dotyczące relacji Jezusa z kobieta$\mathrm{mi}^{{ }^{2}}$. Jakkolwiek sięgając po publikację T. Eagletona - osoby bardzo jednoznacznie określonej politycznie i światopoglądowo - naiwnością byłoby się spodziewać wywodu przychylnego dorobkowi myśli chrześcijańskiej, to jednak jawnie prowokacyjna postawa autora spowodowała, iż uznałem za konieczną niniejszą wzmiankę.

Podobnie zaskakująca może się wydać polskim czytelnikom teza o braku historycznego zjawiska stosowania metod terroru przez orędowników socjalizmu ${ }^{13}$. Polemikę $\mathrm{z}$ przedmiotowym stanowiskiem uważam za zbędną.

Reasumując powyższe, podkreślić trzeba, iż zasadniczo publikacja prezentuje interesujące spojrzenie na współczesne problemy relacji dwóch wielkich, często postrzeganych jako opozycyjne cywilizacji. Autor w wyrazisty sposób prezentuje swój punkt widzenia, niekiedy przytaczając argumenty, mogące wzbudzić u czytelnika szok. Niewątpliwe Święty terror jest głosem w dyskusji znamiennym dla zachodniego nurtu myślenia ostentacyjnie i bezkompromisowo lewicowego, co sprawia, iż publikacja ta nie może pozostawić odbiorcy obojętnym, bez względu na jego osobiste przekonania.

Główna teza publikacji jest konsekwencją założenia o wspólnych podstawach kulturowych i, nade wszystko, etycznych kultury islamu i świata chrześcijańskiego. $\mathrm{W}$ przekonaniu piszącego te słowa pozostaje ona nieobroniona. Skonkludować należy zatem, iż wspierając się na błędnych przesłankach, Eagleton doszedł do równie mylnych wniosków. W moim przekonaniu autor potraktował problematykę relacji świata zachodu $\mathrm{z}$ terroryzmem nazbyt wybiórczo, skupiając się na usilnym poszukiwaniu kolejnych argumentów dla swej podstawowej tezy. Przywołać w tym miejscu warto przeciwny punkt widzenia, którego podstawą jest stwierdzenie, iż „i judaizm, i chrześcijaństwo, i islam wyprowadzają swój początek od objawienia się Jedynego Prawdziwego Boga Abrahamowi. Jednak to, co wyłoniło się z

średnio sprzeciwienie się próbom przedstawiania kultury zachodniego chrześcijaństwa jako pokrewnej względem świata dżihadu. Papież w szczególności podkreśla odwieczność toczącego się sporu cywilizacyjnego między dwiema religiami, cytując fragmenty średniowiecznego dialogu bizantyjskiego cesarza Manuela II Paleologa z uczonym Persem. Tekst wykładu dostępny jest na stronie internetowej o adresie: http://www.fidelitas.pl/pdf/ Benedykt_16_wyklad_w_Ratyzbonie.pdf.

T. Eagleton, Swięty terror, s. 56.

Tamże, s. 161. 
tego wspólnego punktu wyjścia, jest bezapelacyjnie różne od siebie nawzajem" $" 14$.

T. Eagleton nie ukrywa, iż ma świadomość skrajnych reakcji, jakie jego punkt widzenia może budzić. Dał temu wyraz już na początku książki, lecz moim zdaniem niniejszy fragment stanowić może dość trafną puentę recenzowanej pracy: „genealogia terroryzmu, jaką próbuję prześledzić od starożytnych obrzędów i średniowiecznej teologii do osiemnastowiecznej wzniosłości i Freudowskiej podświadomości, może się wydawać nie tylko arbitralna, ale przewrotnie ahistoryczna" ${ }^{15}$.

W O J C I E C H S OW I ŃS K

${ }_{14}$ Zob. skrypt wykładu G. Weigela zatytułowanego Fatih, reason and war against jihadism, wygłoszonego w Foreign Policy Research Institute w Filadelfii; opublikowany został na stronie internetowej o adresie http://www.fpri.org/transcripts/20080204.weigel. faithreasonjihadism.pdf. Cytat pochodzi z fragmentu książki G. Weigela pt. Wiara, rozum $i$ wojna $z$ dżihadyzmem, która ukaże się nakładem wydawnictwa Fronda. Fragment przekładu został opublikowany na stronie internetowej o adresie http://www.fronda.pl/news/czytaj/george weigel_islam.

15 T. Eagleton, Święty terror, s. 8. 